\title{
OSPREY NESTING SUCCESS IN WEST-CENTRAL SASKATCHEWAN
}

FRANK SCOTT, Box 90, Loon Lake; Saskatchewan, SOM 1 LO and C. STUART HOUSTON, 863 University Drive, Saskatoon, Saskatchewan. S7N 0J8

The concentration of Ospreys near Loon Lake has been followed continually since 1975 . The study area extends $43 \mathrm{~km}$ west, $14.5 \mathrm{~km}$ north and $22.5 \mathrm{~km}$ south of the village of Loon Lake, but only the forest trees near lakes and ponds are searched intensively. One of us (FS) has flown over all known nest sites in early May to see which were occupied. A second visit identified active nests containing eggs. In early July all active nests were visited to see which had been successful and to determine which of the trees were climbable.
Over the 8 years the number of known nests has increased. In part this represents better coverage of the area, although there may have been a real increase in the number of nests in 1982. We know of some nests that are new, but others at a considerable distance from water may have been previously overlooked. The distribution of active nests has varied from year to year. Those nests used for only one year are most often unsuccessful. Other nests have been consistently successful.

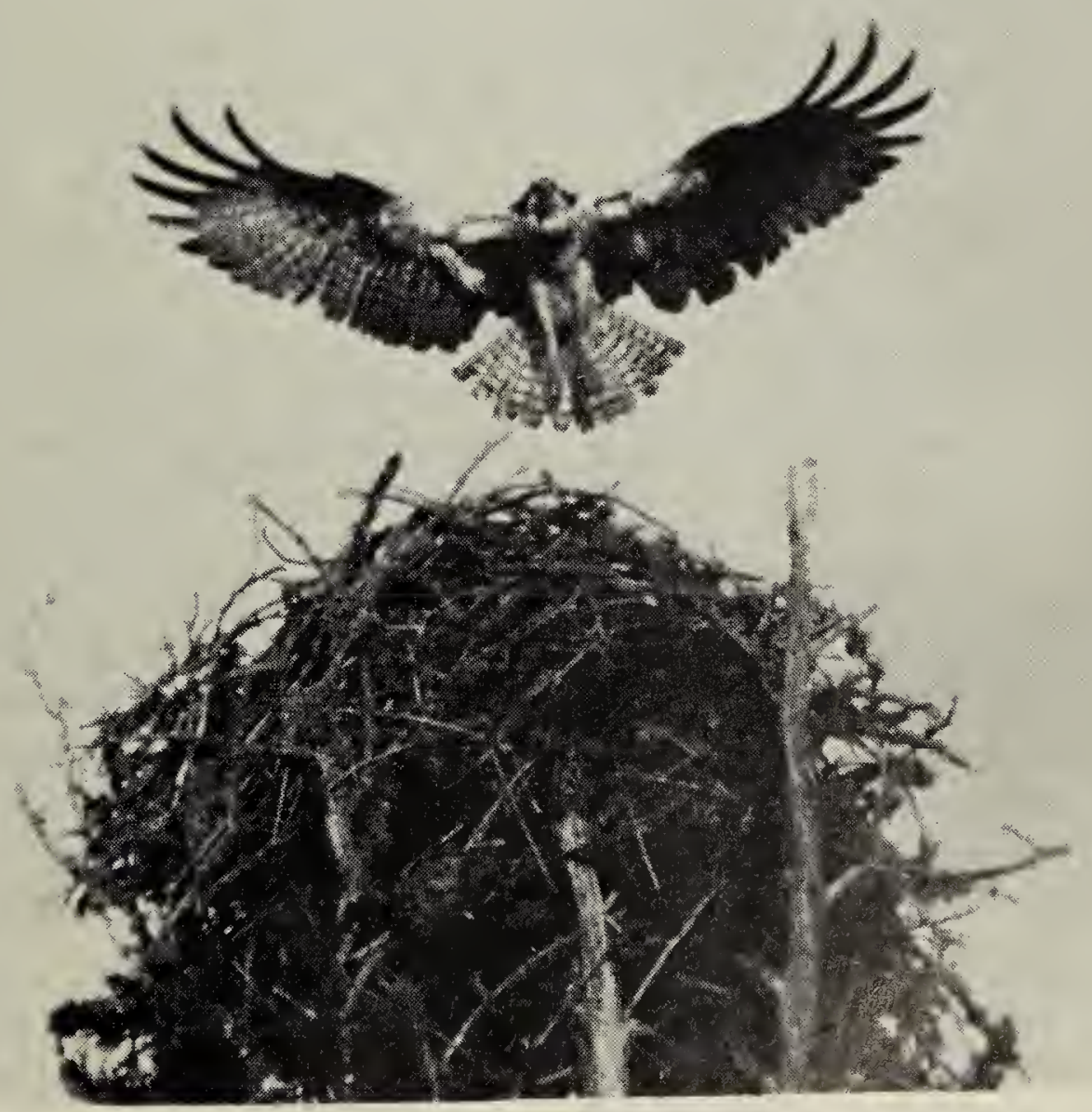


All banding has been done in mid- to late July, when the young were large enough. However, we may have been too late at least once in each of 1975 and 1981, when one young had fledged before we climbed the tree. Whilst it is difficult to count young from the air, in each the number banded was less than the number seen in the nest a day or two earlier. Also, in 1979, two young from a nest close to a gravel highway were found sitting on the side of the road whereas the previous day both had been in the nest. Only once, on 21 July 1979, was a late nest encountered where young were too small to hold bands without the use of waterproof adhesive tape to hold the band in place for a few days until the leg grew to fit the band.

Nest visits were made using a Piper PA 18150 equipped with floats, flying to within $20 \mathrm{~m}$ above and to one side of a nest at 80 to $100 \mathrm{~km} /$ hour. This allowed a good view to both pilot and observer. Eggs were easy to see and count. Young were more difficult to see since they lay flat and bunched up, blending well with the lining material of the nest. Sometimes young were countable, but at other times we could only say that young were present, maybe 1 or 2 or 3 . Over the years our assessment of nests has improved. Unproductive nests climbed have been mainly deserted nests containing addled eggs in midJuly; such eggs are given to the Canadian Wildlife Service for pesticide level determinations.

The easiest nests, with branches, 22 occasions in all, were climbed by one of us (CSH; all but one of these trees was alive). The other 26 successful climbs, involving more difficult trees, were made by Bruce Donovan (8), Kim Hruska (5), Richard L. Ehman (4), Jim Bardwell, David L. Surkan, Ken Simes and Kelly Wylie. Donovan was hit in the face by a fish carried by a diving parent Osprey and Kim Hruska had his scalp raked open by Osprey claws, requiring sutures, antibiotics and a tetanus booster shot. We have since worn safety helmets for Ospreys as well as owls. The decision as to whether a particular tree is safe to climb rests with the climber. Two dead trees deemed unclimbable in earlier years were climbed safely in 1981 and 1982.

Having looked at the decrepit state of 2 dead nest trees in 1977, both in imminent danger of falling over, and knowing of the success of nest platforms in Michigan and Ontario, we decided to erect artificial nesting platforms in March 1978, aided by Bruce and Betty Donovan. By then it was warm enough. to work outdoors although the lakes were still frozen, making ski-doo access easy. The sites chosen were: 1. Near a nest which had fallen down that winter but which had been consistently successful; 2 and 3 were regularly productive nests in dead trees - one a low Jackpine which we easily pushed over by hand, the other a tall spruce, the top half of which was rotten and decayed. Neither tree had much chance of standing another season.

Each nest platform was a $4 \mathrm{ft}$. by $4 \mathrm{ft}$. sheet of 1-inch thick plywood with a row of $1 / 2$ inch dowels set in from the edge to hold the nest material. ${ }^{10}$ The top of a suitable tree was lopped off and the platform was cantilevered out from one side using 6-ft. long 2" by 6" lumber fastened to the tree with lagg bolts; the platform was just below the truncated top. No. 1 was too far from the old nest for the nest material to be placed on the platform. It has not been used. No. 2 was in a low 20-ft. Jackpine very close to the old nest in the tree we pushed over. We transferred nest material to the platform which was a similar height with an unrestricted view of the lake. That year 3 young Ospreys were reared on it. While interest has been shown in succeeding years, no eggs have been laid since. No. 3 was made by placing the 2" by 6" lumber as a bridge between the live lower half of the nest tree 


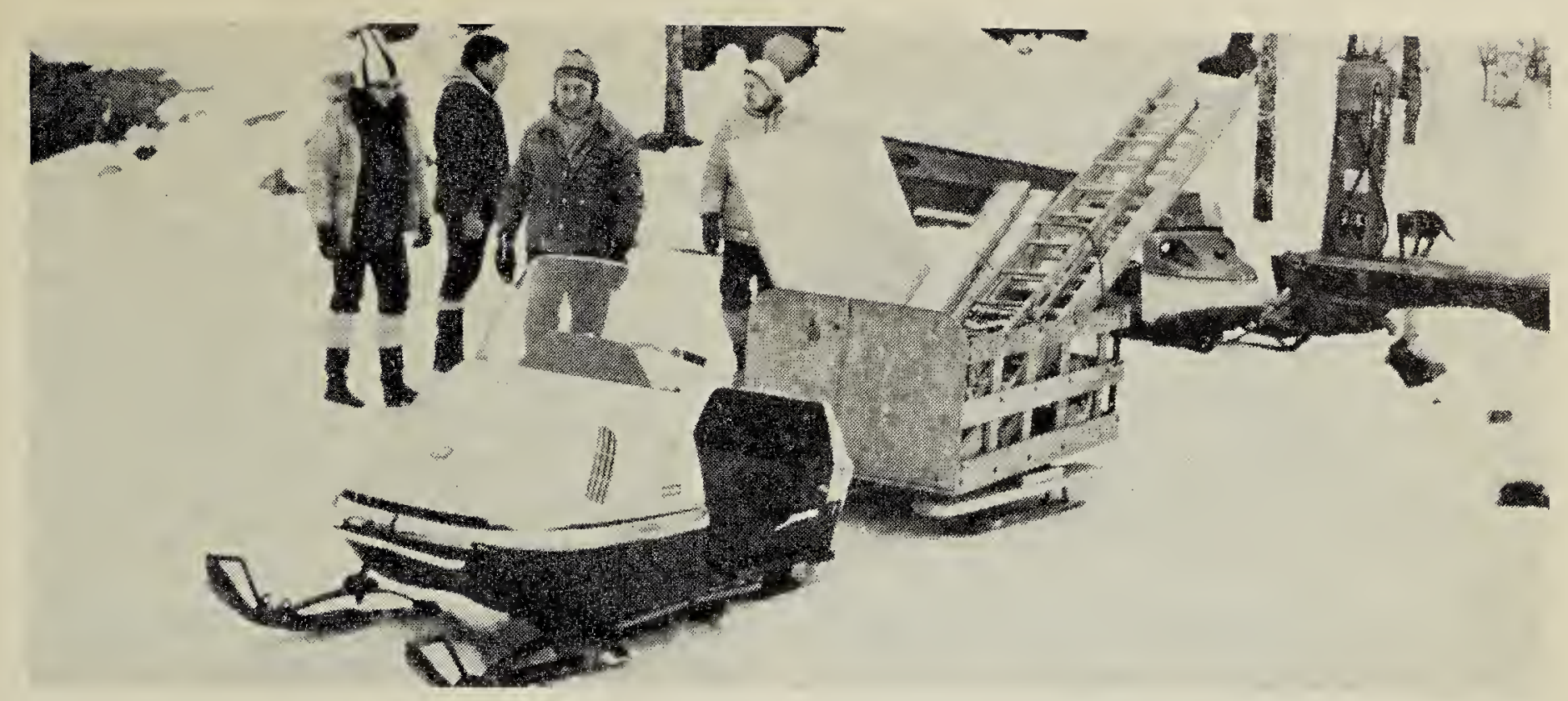

Osprey platform building crew at Loon Lake, left to right: Betty Donovan, Bruce Donovan, Frank Scott, Mary Houston.

and an adjacent Spruce. The platform served as a bridge between the tops of the two stumps. To it we added nest material from the previous nest that was about $8 \mathrm{ft}$. deep. This platform has not attracted any Osprey attention.

From our observations in this area, Ospreys are unable to build a nest in time for use the same year. Therefore dead trees are a potential hazard. When an occupied tree falls it will mean loss of production that season, as well as the following season while a new nest is being built -- if there is no alternate nest nearby. In 1982 a dead tree with an active nest toppled during a storm about 2 weeks prior to the banding expedition. By extreme good fortune the tree fell against the only nearby living tree and lodged there. The 3 young were banded by climbing the live tree. After the breeding season the nest tree fell completely. There is another nest close by in a dead but climbable tree.

An active unclimbable nest which fell during the '77-'78 winter had a pair on territory nearby in 1978 and by 1979 the new nest within 25 yards was successful. At another site no fewer than 4 Ospreys were seen building a single nest in 1978. Interest was shown in the nest in 1979 and 1980 but not in 1981 . This nest finally contained eggs in 1982 but was unsuccessful.

Each year there are a few pairs of Ospreys present that do not lay eggs. In 1982 there were three such pairs in attendance at previous nests, while four pairs built new nests but failed to lay eggs. We do not know their age put speculate that some of these Ospreys may be only 2 years old.

\section{Discussion:}

Osprey nest density near Loon Lake is higher than for any other known area in Saskatchewan, or indeed in Canada between the Great Lakes and the Rocky Mountains -- an average of just over 20 active nests per $620 \mathrm{sq}$. mi. or 1 per $80 \mathrm{~km}^{2} .{ }^{6}{ }^{2}$ This compares with 1 nest per $1680 \mathrm{~km}^{2}$ in northwestern Ontario. ${ }^{2}$

Nesting success and productivity in this population were high from 1975 through 1982 (Table 1). Of 158 active nest attempts $65 \%$ produced young, with an average of 2.06 young banded in 48 successful and climbable nests. This compares with $48 \%$ to $60 \%$ nest success in a successful population in Oregon. ${ }^{4}$ The brood size of $2.06 \mathrm{com}$ - 
pares favourably with a brood size of 1.35 to 1.69 found in Minnesota between 1963 and 1968, and a figure of 1.48 in Sweden. ${ }^{18}$

If we assume equal production for the 55 Loon Lake area nests not climbed, we would have another 113 young, or a total of 212 young produced near Loon Lake in 8 years, or 1.34 young per occupied nest. This compares with figures of 0.93 to 1.37 for the Oregon population. $^{4}$

In nearly half $(48 \%)$ of our successful climbable nests we banded 2 young, with a similar $(46 \%)$ contribution to total production. Only 14 nests had 3 young yet these nests contributed $42 \%$ of the total production.
Osprey nesting success is an important indicator of the contamination of our environment. Along the eastern seaboard, particularly in Connecticut and Rhode Island, coincident with high levels of biocides in the environment, Osprey productivity fell to only .23 young per occupied nest in 1963-67 and the population fell to $10 \%$ of its former numbers. A slow recovery since has paralleled the reduction in use of DDT. ${ }^{3}$

Henny and Van Velzen have shown that Ospreys from the eastern United States winter in the West Indies and South America, chiefly in Brazil, extending far up the Amazon, and in Venezuela and Colombia. ${ }^{5}$ A smaller

Table 1. OSPREY NESTING SUCCESS NEAR LOON LAKE

Banding

Visit

$\begin{array}{rrc}\text { 26 July '75 } & 15 & 3 \\ \text { 17-18 July '76 } & 20 & 8^{\text {a }} \\ \text { 23-24 July '77 } & 20 & 5 \\ \text { 22-23 July '78 } & 20 & 8 \\ \text { 21-22 July '79 } & 20 & 8^{\text {b }} \\ \text { 26-27 July '80 } & 20 & 11 \\ \text { 18-19 July '81 } & 21 & 5 \\ \text { 10 July '82 } & 22 & 7^{c} \\ \text { TOTALS } & 158 & 55\end{array}$

No.

$\begin{array}{rr}\text { No. No. } & \text { Successful } \\ \text { Active } & \text { Failed } \\ \text { nests nests not } \\ \text { nests } & \text { climbed }\end{array}$

No.
Total

nests Nests with young climbed 1 yg. 2 yg. 3 yg. banded

\section{a One nest climbed after 2 weeks of cold, wet weather in 1976 contained 3 dead young.}

b One nest contained only 1 addled egg.

c Two nests each contained only 2 addled eggs.

Other addled eggs in successful nests: 2 eggs with 2 young twice in 1977, 1 egg with 1 young in 1978, 1 egg with 2 young in 1978, 1 egg with 2 young in 1981 . Total in 8 years, 12 addled eggs in nest at banding visit. Also, there was 1 dead young in a nest with 2 live young in 1978; total in 8 years, 4 young ospreys dead in nest. 
number winter on the western side of the continent, in Ecuador and Peru. They remain in South America as 1-year-olds but a number of 2-year-olds return as non-breeding birds to the approximate area of their birth, and thereby form an estimated $6 \%$ of the population on the breeding grounds, where they may build nests but do not lay eggs. ${ }^{5}$

Although the sample is small, it seems probable that most of the Loon Lake Ospreys winter along the northwestern coast of South America, and the adjacent inland rivers. Three of the 4 recoveries to date are in a straight line, from inland on the equator in Ecuador, north to the coast 3 degrees north of the equator in Colombia, a distance of $375 \mathrm{~km}$ (Table 2 and Figure 1). All were within 1 year of banding; the one in early June is consistent with other evidence that year-old birds remain on the wintering grounds without returning north.

Results from Ospreys raised in Idaho and eastern Washington have resulted in 14 recoveries from 254 nestlings banded. Other than Idaho (2) and Texas (1), there have been 5 recoveries from Mexico and 6 from Central America, but none from South America. ${ }^{7}$ It may be that, as with several other species, the most northern individuals "leap-frog" over the more southern nesters to winter farther south.

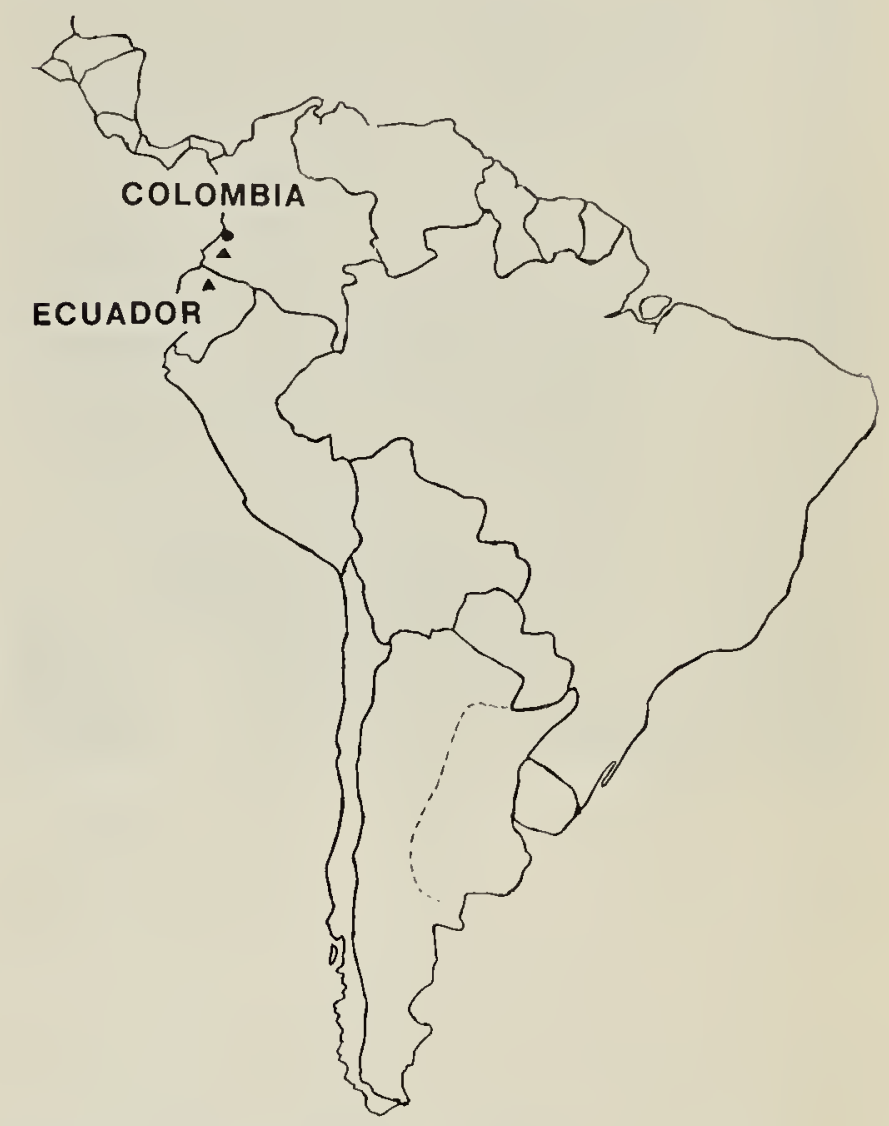

recovery within six months of banding

A recovery more than six months after banding

Figure 1. Osprey Band recoveries in South America.

Table 2. RECOVERIES OF OSPREYS BANDED NEAR LOON LAKE Band Number Banding and Recovery Locations

608-31261 Peck Lake (5350' $\left.\mathrm{N}, 109^{\circ} 30^{\prime} \mathrm{W}\right), 23$ July 1977. Shot $13 \mathrm{~m} \mathrm{~N}$ of Timbiqui, Colombia ( $\left.2^{\circ} 50^{\prime} \mathrm{N}, 77^{\circ} 40^{\prime} \mathrm{W}\right)$ in October 1977.

608-10957 Loon Lake West (54.00' $\left.\mathrm{N}, 109^{\circ} 10^{\prime} \mathrm{W}\right), 27$ July 1980. Shot at Atahualpa, Ecuador $\left(00^{\circ} \mathrm{N}, 109^{\circ} 20^{\prime} \mathrm{W}\right)$ on 25 February 1981

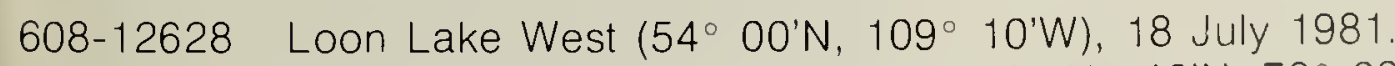
Shot at Barbacoas, Narino, Colombia ( $\left.1^{\circ} 40^{\prime} \mathrm{N}, 78^{\circ} 00^{\prime} \mathrm{W}\right)$ in early June 1982.

608-12631 Branch Lake, (540 $\left.00^{\prime} \mathrm{N}, 109^{\circ} 30^{\prime} \mathrm{W}\right), 19$ July 1981 . Found dead at Lake Colorado City, Texas (32 $\left.20^{\prime} \mathrm{N}, 100^{\circ} 50^{\prime} \mathrm{W}\right)$ on 15 October 1981.

'Two others have been found dead near the foot of their nest tree, the following month, and 2 years after banding. 


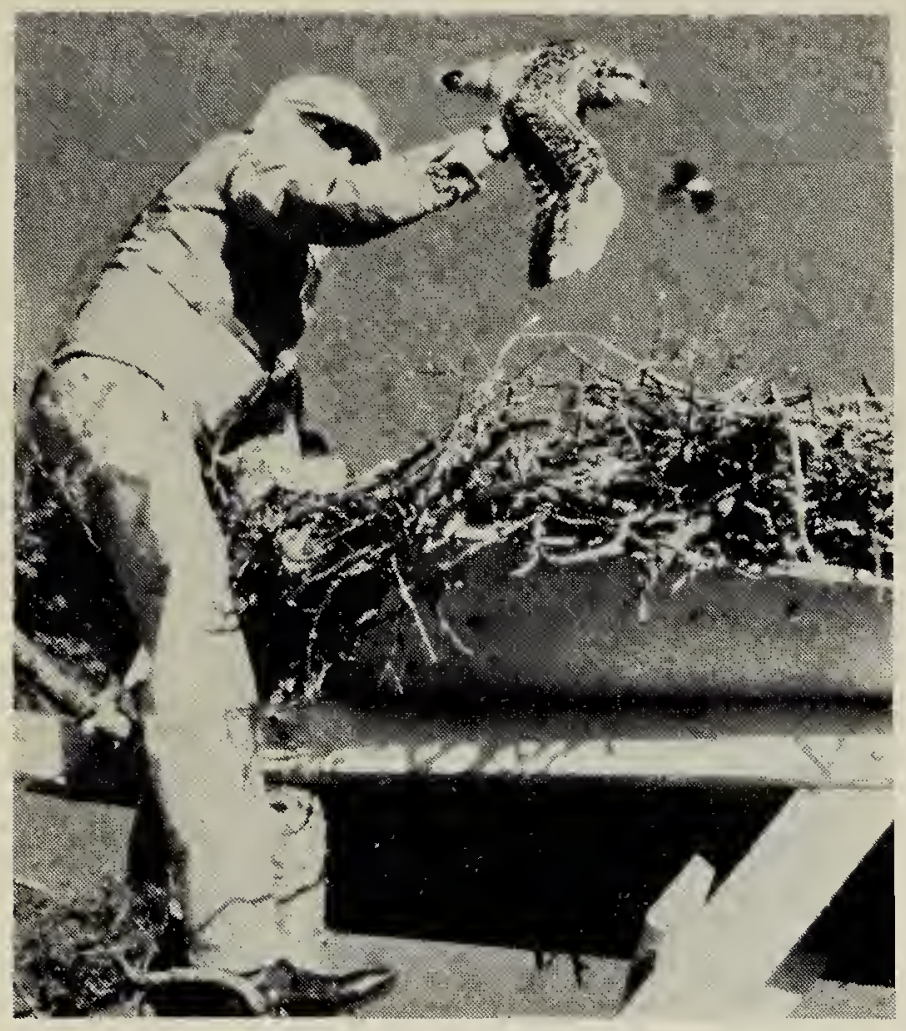

C.S. Houston at Osprey nest platform, Loon Lake

Frank Scott

Artificial nest platforms have had great success in Michigan, and in Postupalsky's main study area most pairs nest on such platforms, reducing nestling mortality from $28 \%$ to $7 \%$ by eliminating blowdowns of nest trees. ${ }^{9}$

Platforms are most useful where Ospreys nest in snags in flooded reservoirs, where good nesting sites are scarce. ${ }^{9} \quad$ Nevertheless, Ospreys sometimes nest on telephone poles between Banff and Lake Louise, even though suitable natural trees are abundant. There is a potential advantage for Osprey nesting success in cutting down those dead trees which are in danger of falling during the next few nesting seasons and in each case offering a substitute platform nearby. Advantages to the bander in terms of safety and accessibility provide additional motivation.

\section{Acknowledgements}

We wish to thank Dr. Penelope Davis and Mary I. Houston for their continuous assistance, our courageous tree climbers who made this study so successful, and J. Bernard Gollop, who provided helpful criticism.
'DUNSTAN, T. C. 1968. Breeding success of Osprey in Minnesota from 1963 to 1968. Loon 40:109-112.

${ }^{2}$ GRAY, P. A. 1980. Bald eagles, herons and ospreys in West Patricia. Ontario Fish and Wildlife Review 19:3-6.

${ }^{3}$ HENNY, C.J. 1975. Research management, and status of the Osprey in North America. World Conference on Birds of Prey, Vienna, 1975. 199-221.

${ }^{4}$ HENNY, C. J., J.A. COLLINS and W.J. DEIBERT. 1978. Osprey distribution, abundance, and status in western North America: 11. The Oregon Population. Murrelet 59:14-25.

${ }^{5}$ HENNY, C. J., and W. T. VAN VELZEN. 1972. Migration patterns and wintering localities of American Ospreys. J. Wildlife Management 36:1133-1141.

${ }^{6}$ HOUSTON, C.S., J.M. GERRARD, D. W. A. WHITFIELD, H. A. STELFOX and W.J. MAHER. 1977. Osprey nesting records in Saskatchewan. Blue Jay 35:38-41.

${ }^{7}$ MELQUIST, W. E., D. R. JOHNSON and W. D. CARRIER. Migration patterns of northern Idaho and eastern Washington Osprey. Bird Banding 49:234-236.

${ }^{8}$ ODSJO, T. and J. SONDELL. 1976. Reproductive success in Ospreys Pandion haliaetus in southern and central Sweden, 1971-1973. Ornis Scandinavica 7:71-84.

${ }^{9}$ POSTUPALSKY, S. and S.M. STACKPOLE. 1974. Artificial nesting platforms for Ospreys in Michigan, in: Management of Raptors. Proceedings of the Conference on Raptor Conservation Techniques, Fort Collins, Colorado, 22-24 March, 1973 (Part 4), F. N. Hamerstrom, Jr., B. E. Harrell, and R. R. Olendorff, Editors. Raptor Research Report No. 2, pp. 105-117.

${ }^{10}$ RHODES, L. I. 1972. Success of Osprey nest structures at Martin National Wildlife Refuge. J. Wildlife Management 36:1296-1299.

"SCOTT, F. and D. L. SURKAN. 1976. An unsuspected Osprey concentration in west-central Saskatchewan. Blue Jay 34:98-99. 